International Journal of Linguistics, Literature and Translation

ISSN: 2617-0299 (Online); ISSN: 2708-0099 (Print)

DOI: $10.32996 / \mathrm{ijllt}$

Journal Homepage: www.al-kindipublisher.com/index.php/ijltt

IJLLT

\title{
Usages for a Conceit: A Comparative Study of Donne's "A Valediction: Forbidding Mourning" and Hāfez's Sonnet 193
}

\author{
Leila Hajjari' 8 (D) Amaneh Zare ${ }^{2}$ (D) and Hossein Aliakbari Harehdasht ${ }^{3}$ (D) \\ ${ }^{123}$ Department of English Language and Literature, Faculty of Humanities, Persian Gulf University, Iran \\ $\triangle$ Corresponding Author: Leila Hajjari, E-mail: Ihajjari@gmail.com
}

\section{ARTICLE INFORMATION ABSTRACT}

Received: June 13, 2021

Accepted: July 19, 2021

Volume: 4

Issue: 7

DOI: $10.32996 /$ ijllt.2021.4.7.2

\section{KEYWORDS}

Donne, Hāfez, conceit, compass,

Sonnet 193, A Valediction:

Forbidding Mourning.
Hāfez and John Donne are both outstanding love poets. The multilayered implications of the universal theme of love and its relation to the two poets' historical, cultural as well as political contexts have encouraged the present comparative study of Donne's "A Valediction: Forbidding Mourning" and Hāfez's "Sonnet 193". The study is based on the hypothesis that the most dominant features of Donne's love poems are the unity of sense and sensibility as well as congruity of reason and passion, whereas in the poems of Hāfez one can witness disjunction and incongruity between love and reason. In addition to explaining the concept of love, both poets have wittily reflected upon the political conflicts of their time, too. This research, therefore, aims at investigating how Hāfez and Donne have used the mathematical tool, the compass, as a conceit, not only to concretize their notion of love but also to express the symbolic significance of the circular movement of that instrument to comment on the meaning of love in opposition to reason and to criticize the political issues of their time.

\section{Introduction}

Hāfez and Donne are both acknowledged to be spectacular love poets of their own time and culture. Khwāja Shams-ud-Dīn Muhammad Hăfez-e Shīrāzì (1315-1390) known by his pen name, Häfez, was the arch practitioner of the Persian sonnet form whose collected poems (Dīwān) is considered to be the "pinnacle of Persian literature" ("Hafez"). His Dīwān is found at every Iranian home, and people, common or elite, read his sonnets and sometimes at certain occasions look for knowledge of their future through a holy ritualistic practice of opening the book abruptly for a prediction, known in Iran as Fāl-e-Hāfez. Hāfez gained international attention a few centuries after his birth in Shiraz when the foremost English orientalist, William Jones, translated his works in the late $18^{\text {th }}$ century. This fame spread throughout Europe to the extent that "the name Hāfiz [became] synonymous with Persian poetry in the literary culture of Europe" (Khan, 2009, p. 43). John Donne, likewise, was the pre-eminent representative of metaphysical poetry, born in 1572 in London; he composed poems filled with "mysteries, paradox, and intricate imageries" which made his poems intriguing and challenging at the same time. "He is particularly famous for his mastery of metaphysical conceits" ("John Donne").

Hāfez's Dīwān is replete with different drawings on and implementation of the theme of love to the extent that in 313 beits (two

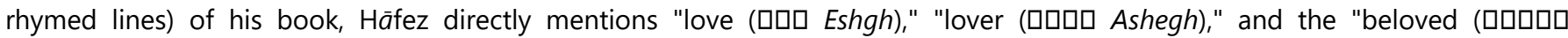
Ma'shoogh)". Similarly, the centrality and omnipresence of the theme of love in Donne's poetry place him among the great love poets of the English early modern poetry. As Naugle (n.d.) puts it,

For the enormously "complex and vexed," (Holy Sonnet 18) John Donne (1572-1631), the one in whom 'all contraries meet', life was love-the love of women in his early life, then the love of his wife (Ann More), and finally the love of God. (1)

\section{K C AL-KINDI CENTER $\mathbf{R}$ DFOR RESEARCH AND} Your gateway to world-class research

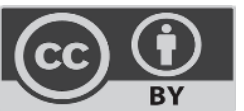

Published by Al-Kindi Center for Research and Development, London, United Kingdom. Copyright (c) the author(s). This open access article is distributed under a Creative Commons Attribution (CC-BY) 4.0 license 
It is interesting to note that Baha-ud-Din Khoramshahi (2013), one of the eminent Hāfez scholars, has pointed to a nearly similar three forms of love in Hāfez's poems; the term, love (عشق Eshgh) which is repeated more than 250 times, can be categorized into three types in the Dînān: human love, aesthetic love (love of poetry/art), and divine love.

To portray love, both poets have used different images and literary devices, among which one stands out to be quite similar, the compass. The similar use of this conceit, which is by definition a far-fetched metaphor, by John Donne has encouraged the authors of this study to investigate the real implications of this usage. Therefore, they have tried to answer the following question: what does the compass as a conceit serve in the poems of the two poets and why? To answer this question, two major objectives, personal and political, of the two poems under the study have been compared. Although the study is based on the comparison, the comparison serves for achieving a greater purpose: finding common grounds between two kinds of literature and nations that are alien to each other. By illuminating the similarity of the two poets' perspective or their differences, a new insight is gained by the readers of both poems, and a cultural familiarity is created between the two English and Persian literature which is the main objective of Comparative Literature study.

\section{Literature Review}

The multilayered nature of Häfez and Donne's poetry has led to countless separate discussions of each poet. Guibbory (2015) wrote about how politics, love, and religion are interconnected in Donne's writing (p. 811). Izadyar (2015) considered Hāfez as a sociologist and an anthropologist rather than a love poet since he mirrors the circumstances of his time in his poetry. Modarres Zadeh and Anushirvani (2016) examined the theme of love in Rumi and Donne's poetry. In his article, he provided the readers with the general illustration of the unique perception of the concept of love in the poetry of Rumi who was the most distinguished Persian Sufi mystic poet, and in the poetry of John Donne, the leading English poet of the metaphysical school. Another comparative study on the subject of love had been undertaken by Sajjadi (2013) who delineated the influence of Hāfez on Goathe. In his article, one can witness the extent that love removes distance and keeps nations and cultures closer. Hadadi and Mousazade (2011) based their study on the hypothesis that the most dominant feature of Hāfez's poetry is the demonstration of the incongruity and disjunction between love and reason. Dezh Abad (2013) demonstrated various types of beloveds in Hāfez's poetry. These beloveds were the demonstration of the physical, mystic, and spiritual aspects of Häfez's love poems. Mousely (1999), after analyzing Donne's Elegies demonstrated his hatred towards Queen Elizabeth as a female monarch as well as the description of this hatred in Donne's private amatory relations which were illustrated in his Elegies. Fathollahi and Hosseini (2014) in their article, "The Political Philosophy of Khawaja Shams al-Din Mohammad Hāfez Shirazi," referred to the fact that Hāfez was called Khwaja (master) since he was the chronicler of the political condition of his own time. They believed that investigating the worldview of Hāfez could provide the researchers with the latent aspects of his political philosophy (pp. 1-2). Mansournejad's (2014) article, "Mahiyate andishe siasi rende Shiraz Hāfez," explores the political terminologies existing in Häfez's Divan to examine whether these terminologies have the same usage in the world of politics or not. He ultimately concludes that most of these terms reveal Hāfez's political thought. He pinpoints some of the political terminologies which are prevalent in Hāfez's Divan such as government (دولت (تكولت Dolat, حكومت Hokumat), power (قدرت Ghodrat, اقتدار Eghtedar), Sovereignty (سلطنت Saltanat, حاكميت Hakemiyyat), and legitimacy (مشروعيت Mashruiyyat) (pp. 73-74). Mansournejad concludes that the existence of these terminologies may rise to three hypotheses:

1) Häfez tries to praise people who were in charge of power to save both his life and his status. 2) Hāfez utilizes admiration of the rulers to allude to his political idea which is usually critical of the rulers of his time. 3) There is a corresponding relationship between Hāfez's mystical imagination and his political ideas. (p. 87)

\section{Methodology}

This research corresponds with the principles of the Comparative Literature study. This method of studying literature aims to find common grounds of analysis between literature that are alien to one another. The reason behind the search for those grounds (which are not only comprised of similarities but also of differences) is to familiarize and hence lessen the effects of being estranged from one another; Comparative Literature pursues a democratic goal and desires to reduce misunderstandings, and in extreme cases atrocities, that often arise from lack of familiarity and knowledge between and among the nations that are geographically, linguistically, and culturally aloof from each other. This study, therefore, concentrates on the theme of love which is a universal theme under the rubric of Comparative Literature to show how two poets who are both spatially and temporally at a distance have thought and felt the same. As Anushiravani (2010) states, "similar issues can be found in the world literature. These similarities are indicators of the universal nature of literature rather than the sign of influence" (p. 44). Eventually, Humans speak different languages, but they feel the same when it comes to the matter of heart and mind. 


\section{Results and Discussion \\ 4.1. Love}

Poets usually use rhetorical devices to turn Love, which is an essentially complicated and/or abstract concept, into a concrete one, hence tangible, for certain needs and goals. Although there are plenty of ways to concretize love using the literary devices, one of the most interesting ones deployed by the 14th-century Persian poet, Hāfez, the supreme connoisseur of the Persian sonnet form, and the $16^{\text {th }}-17^{\text {th }}$-century English metaphysical poet, John Donne, is conceit, or the far-fetched metaphor. Häfez uses compass as a conceit to be able to convey his mystical as well as political ideologies of and about love; Donne uses it to elaborate on his metaphysical notion of body versus soul in light of the idea of love. Both poets, as we are going to show, are poets of love who are concerned with its conflicting aspects, the spiritual and the political, the sacred and the mundane, the emotional and the rational, the personal and the socio-political. To delineate this duality, they found a compass as the best means.

In Hăfez's poems, to begin with, one can witness the permanent existence of the idea of incongruity and disjunction between love and reason and/or the lyrical/personal/passional and the rational/social/political, the former in this binary relation taking the dominant position. Hadidi (2011) asserts that in many cases, Hāfez gives priority to love's spiritual power and criticizes the worldly intellect or reason on account of its limitation to comprehend the true essence of love (p. 59). Hâfez, in Sonnet 193, for instance, utilizes the compass to juxtapose and oppose love and reason. In the beit (a combination of two lines of poetry) "The wise are the center of the compass of existence / But love knoweth that, in this circle, they head-revolving are" ( عاقلان نقطه $ى$ يركار وجودند ولى (عشق داند كه در اين دايره سرگردانند /Äghelan noghteye pargäre vojoodand vali / Eshgh dänad ke dar in däyereh sargardänand]) (Clarke, 2001, pp. 3-4), the relationship of the two concepts, that is, love and reason, is evident. However, different interpretations of this line help us have a better perception of the incongruity between love and reason. Iränfar (2007) emphasizes the concept of love and asserts that the wise are the center of the compass of existence, but only love apprehends that the wise are not in the center; in fact, they are only roaming in the sphere of the circle; thus, paradoxically love itself is in the center (p. 63). The fact that Häfez mentions the singular word of "love" and the plural "the wise" can be a confirmation of the reliability of Iranfar's interpretation since the center of the circle can only be the position of one entity. Therefore, the word circle refers to the circle of love and the wise are wandering about on and around the sphere of this circle.

The word "head-revolving" expresses a pun which can refer both to the act of wandering and to the way the wise as the moving leg of the compass revolves around the firm leg, which is love, at the center; they are unable to reach the center of the circle. By stating that "love knoweth" Häfez intends to express that the interrelation between love and reason is irrevocable; it is Love that knows, not the wise, hence love's meaning transcends the mundane or secular meaning; it is allegorized to mean the Beloved, the mystical Form, the Ideal and the Idea. This Love has knowledge by which it can conceive the nullity of worldly intellect.

It is worth mentioning here that the word circle which is an effect of or an image drawn by the compass has various functions. As Bagheri Khalili and Mehrabi Kali (2014) put it, as opposed to Saadi who utilizes the word circle in his poems to refer to both a complete circle and a spiral, Häfez always refers to a complete circle when he mentions the word in his poems. He continues to say that circle in Häfez's poetry can be an indication of three main concepts. The first concept is demand (talab). This demand can be for love, beloved, and wine. The second concept is the complaint (shekvah). The third concept is submission (taslim) through which Häfez intends to indicate the complete finite circle to emphasize both the function of time and fortune (p. 132).

Another interpretation of Häfez's famous beit of the putative sonnet which puts more emphasis on the function of the compass and its circular effect, the image drawn using this mathematical tool is by Ebrahim Dinani (2012). He expresses that, concerning what we learn from Hāfez's sonnet, only a skeptic person would not consider existence as a complete circle. He explains that when Hāfez considers the wise as the center of the compass of existence, it is a kind of allusion to the wisely created existence as in another sonnet, sonnet 77, the compass is the vehicle of creation in the hands of the Creator: "Rise to give our souls for the Painter's reed-pen / Who in the movement of his compass [emphasis added] has many wonderful shapes". This existence has a specific beginning and a specific end. Hāfez surpasses the demonstration of reason and loving relationship and considers Love which has knowledge as a booster of intellect to emphasize existence as a complete circle metaphorically shown as an effect of the compass, the Creator's shaping/drawing tool.

John Donne, likewise, depicts love's requirements in "A Valediction" by utilizing the compass as a far-fetched metaphor or a conceit. By considering the two feet of the compass as the lover and beloved's souls, John Donne demonstrates the dependency of the lover and beloved on each other as well as the persistence in love. The illustration of this dependency in love culminates in the act of leaning one foot of the compass toward the other one. "And though in the center sit/ yet, when the other far doth roam/ it leans and hearkens after it" (II. 29-31). This tendency and interdependency of the two legs of the compass can illustrate the final consequence of love which is submission. In this regard, Hăfez, too, glorifies a type of love that is omnipresent with perpetual knowledge or learned supremacy of the steadfast love over the roaming intellect, or the celestial soul over the mundane body. He 
depicts taslim (submission) to the knowledge induced by love emphasizing that only Love knows that the wise are head-revolving in the circle of existence like the moving foot of the compass around the fixed leg, that is the center.

As in many of his love poems, John Donne in "A Valediction Forbidding Mourning," engenders a dichotomy between the common love of the everyday experience and the uncommon love of the speaker that emphasizes the sacred nature of love. "Donne's love poetry plays on and stands in contrast to Neoplatonic and Petrarchan dualism where it was believed that the soul wanted nothing to do with the body" (Rivers, 1994, p. 34). However, the contradictory point of Donne's love poems is his expression of a position where the lovers possess the body and transcend it at the same time. According to this contradiction, the degree of priority that Donne gives to the physical and the spiritual love varies in different poems. Another intriguing feature of Donne's love poetry is his illustration of a paradox of how the lovers can be both two and one at the same time. "A Valediction: Forbidding Mourning" revolves around this mysterious union that makes two become one, and also it demonstrates how the power of love, which depends on merging identities of two lovers in one soul, can cancel out the separateness of the individual lovers.

In "A Valediction," John Donne expresses his love for his wife, Ann More. He compares his beloved's soul to the fixed foot of the compass, and his soul to the roaming foot of the compass. He admits that he and his beloved may have two souls rather than one; however, he develops the connectedness of their two souls by comparing their souls to the twin feet of the compass that connect with each other by the same point. The utilization of the compass can be an allusion to the ancient love theory as held by Plato and Ficino. We learned from both that "man was originally one, containing both male and female, but later separated. As a result, lovers seek to reunite the two halves and become whole again and this pursuit where they melt into one another is called love" (Cirilo, 2016, p. 87). By using the word soul, Donne intends to give priority to the spiritual nature of love rather than a physical one. The word soul refers to "an entity distinct from the body; the essential, immaterial, or spiritual part of a person or animal, as opposed to the physical" (OED). Thus, the only way to become whole or one again is through love which is spiritual and transcends the realm of the physical body. As a result, the compass is the perfect illustration to encapsulate the values of Donne's spiritual love, which is symmetrical, balanced, intellectual, and glorious in its polished simplicity. As Donne demonstrates it in the poem,

If they be two, they are two so

As stiff twin compasses are two

Thy soul, the fixed foot, makes no show

To move, but doth, if the other do (II. 25-28).

The twin feet of the compass may take distance from or draw closer to one another in different diametrical lengths of the circles; however, this distancing is conditioned by time. Identical to the twin feet of the compass, separation may happen to the lovers, but it cannot affect the purity of the lovers' amatory relation since their relationship is based on consistency which is established by the beloved's soul. According to Greteman (2010), the poem argues that the soul is superior to and not dependent on the physical, and claims that love can continue despite physical separation ( $p .32)$. Thus, spiritual love between the lovers admits absence even though this separation is not a permanent one. Targoff (2008) argues that the poem conveys "a love that needs no substantial embodiment, a love that can survive on a purely spiritual plane" (p. 71). In this part of the poem, John Donne correlates the function of the compass and the relationships between the lovers.

Such wilt thou to me, who must,

Like th' other foot, obliquely run;

Thy firmness makes my circle just,

And makes me end where I began (II. 29-32).

The circular movement of the compass stands for Donne's notion of love and life at the same time. Donne's notion of life, in Freccero (2015) words, "is a Circle, made with a Compass, that passes from point to point; that life is a Circle stamped with a print, endless, and Perfect Circle, as soon as it begins" (p. 339). John Donne utilizes the circular imagery for both worldly lives that implicates earthly experience and the life to come that implies eternity. Donne emphasizes that the earthly and human experience 
is like a finite circle; it starts from a specific point and ends in a specific point; thus, it can be measured by time and space. Donne signifies eternity by an infinite circle. "No finite circle can express the all-encompassing dimensions of eternity, nor can any localized center give a hint of its omnipresence" (Freccero, 2015, p. 340). Hence, when Donne expresses his notion of eternity, he illustrates an endless circle which is more like a spiral rather than a complete circle since it is an endless circle. According to Frecerro (2015), human love "pulsates between the eternal perfection of circularity and the linear extension of space and time" (p. 336). Thus, the compass describes the expansion of the lovers' spirit, and the lover's return to his beloved perfects the circle making it complete. The common point of the compass acts as the point of eternity in which the lovers share one common soul. The soul of the lover and the beloved together construct the soul of love and the center of the circle is their common position. By glorifying spiritual love, Donne attempts to manifest the eternal essence of love so the word circle in this stanza refers to a spiral rather than a complete circle.

The notion of love which is indicated by these two poets defines the praiseworthiness of love to be celebrated as a concept that transcends the material world, either the physical body or the terrestrial intellect. It is an outstanding human quality. It is, in general, associated with some requirements such as the competency of the lover, persistence in love, and the favor of the beloved. If one meets all these requirements, it will lead to the ultimate phase or status which, as in the case of Hâfez's lover, is acceptance and submission (Karimi, 2015, pp. 143-145). Therefore, both poets place love at the center of the circle which is mentioned in their poems. Despite describing various types of love, both Häfez and Donne delineate the power of love as well as its ultimate effect or achievement, that is, submission to the will of the beloved while holding steadfastly onto the center. The difference lies probably in the fact that for both poets the beloved takes different quality; to Hāfez, the beloved is hardly imaginable in the sphere or realm of matter whereas to Donne, it can hardly trespass the bounds of earthly presence.

\subsection{Politics}

One of the substantial potentialities of Häfez and Donne is that they can not only expound on and dramatize love and passion, hence creating an emotional/romantic atmosphere in their poems, but also reflect the socio-political circumstances of their own time using or under the guise of this universal theme. Therefore, it is not difficult to notice the political under/overtones of their love poems. In Hāfez, very often love serves as a means to satirize the religious fanatics who are actually in power in society. He does it sometimes using wit and sometimes quite openly. Donne, nonetheless, has a rather more oblique way of criticizing those who are in power. Interestingly, the two poets deploy the putative compass as a conceit to remain immune to the threats of the powerful addressees of their poems.

Häfez was subject to sovereign rulers witnessing the reign of different monarchs in his lifetime. Therefore, knowing about the socio-political conditions of his time can help excavate other hidden meanings of his poems. Ashouri (2016) believes that to have the hermeneutic perception of Häfez's poems one must consider the poem's correlation to its historical background and should accept the historical caliber of his ideas (tarikhiate andishe) as the basis of his poetry (p. 20). According to Izadyar (2015), Hāfez is a sociologist and an anthropologist rather than a poet. He is the chronicler of the political and social conditions of his own time. He attempts to mirror the circumstances of his time in his poetry. Poetry is how he struggles against the ruthlessness of life (p. 22). Mansournejad (2014) argues that Hāfez depicts many conventional political factors in his Diwan (p. 76). These factors are the priority of the ruler over ordinary people, lack of general expedient people, and ruler relationship which is identical to the relationship between the shepherd and the sheep. "Many of Häfez's poems that have a critical tone were written during the reign of Mobarezal-Din" (Izadyar, 2015, p. 22). In many of his sonnets (ghazals) in his Diwan, Hāfez attacks this hypocritical and oppressive Islamic dictator.

Mobarez-al-Din, whose bloody and murderous nature was notorious, pretended to respect the Islamic rules. Thus, he commanded all the taverns to be closed. "He went to such excesses in prosecuting 'vice' and commanding people to pursue 'virtue', that the wits and the comics of the metropolis soon mocked him with the sobriquet 'the policeman' [muhtasib]" (Lewishan, 2010, p. 23). Lewishan (2010) explains that this kind of religious dictatorship made Hāfez elaborate his well-known symbol, the inspired libertine (rind), as a representative of the spiritual and intellectual counter-culture of the city. This line of Sonnet 193, "Poor are we; and desire for wine and the minstrel, we have: Also! If, in pledge, the woolen khirka they take not"([Moflesanimo havaye meyo motreb darim/Ah agar khergheye pashmin be gero nastanand]) (Clarke, 2001, pp. 9-10), indicates Häfez's complaint to the deed of this pretentious Islamic dictator, especially his commandment of the closure of the taverns.

The compass metaphor in the afore-mentioned sonnet has its political edge as well and has been beautifully utilized by Hāfez to criticize the dizziness of those who assume to be wise who know better what benefits people and what harms them, the very common notion of "thou shalts and thou shalt nots" of every religious discourse and doctrine. The lines (beit) in Sonnet 193, "The wise are the center of the compass of existence / But love knoweth that, in this circle, they head-revolving are" ([Äghelan noghteye pargäre vojoodand vali / Eshgh dänad ke dar in däyereh sargardänand]) (II. 3-4), gives evidence to the fact that Hāfez contrasts 
those who see by the constant love and those who judge by the wandering/bewildered reason, especially by the ideological or religious reason. However, ironic, it attests to Hāfez's mystical approach to life. For Hāfez like all other great Persian mystics such as Farid al-Din Attar, Rumi, and Sa'di, love is the wing the exalts the soul and lets the mind soar in realms that are alien to the mathematical minds. Häfez's witty and playful usage of the compass is ironic and shows his cleverness to turn the means of (mathematical) reasoning against it. Estelami (2014) has pointed out that the wise are those who concern themselves too much with the profits or harms of life and existence whether here or the world to come (p. 501); therefore, these intellectuals who consider themselves as to be wise are unable to comprehend the real essence of life which in Hāfez's opinion is love and living by its law.

In Hāfez's sonnet 193, the fixed foot of the compass is assigned to the wise, just to deconstruct this notion immediately on the following line of the poem. Why does he utilize the plural noun, Äghelan (the wise)? On the one hand, Hāfez utilizes Äghelan elegantly to allude to the inconsistency and temporality of the status that people in charge of power, i.e., pretentious rationalists like Mobarez-al-Din, possess. On the other hand, he extends his criticism to all the hypocrites. Häfez attempts to say that people like Mobarez-al-Din assume themselves to be the sole and eternal ruler of the people, comparing themselves to the fixed foot of the compass. But if it were a safe and permanent position, there would be no need for several Äghelan (wise people); only one would be sufficient. In addition, there is a pun in the word "head-revolving" that signifies both the unsteadiness of the fixed foot of the compass, assigned to the bewildered wise who are not able to conceive the definition of love and the malevolence of Mobarez al-Din. He decapitated lots of culprits while he was reciting the Quran without pausing his recitation, "I've heard rumors that you've executed 1000 people by your hand', Shah Shuja asked his father [Mobarez ah-Din].' on the contrary, it was only 800 in maximum,' came the reassuring riposte" (Lewishon, 2010, p. 24).

John Donne, likewise, wrote most of his Elegies during the 1590s when England was ruled by Elizabeth I, a self-centered woman, the ruler of the patriarchal society in which women were subordinate to men. Her sovereignty was a great encouragement for the oppressed women but for men, there were tensions inherent in the submission to the authority of a female ruler, "Tensions over submission to the female rule are strikingly evident in Donne's representation of private love relationships in his Elegies" (Mousely, 1999, p. 28). In most of his Elegies, Donne rejects the female dominance in his private amatory relation which can lead to his rejection of female rule in the public world. Donne expresses his dissatisfaction with female authority by mocking the convention of Petrarchan love sonnets which are written in imitation of Petrarch and characterized by "their platonic love for an impossibly idealized and ethereal mistress" (Siegel 2015, 164). As Guibbory states in his article, Donne attempts to express his selfaggrandizement not only in amatory relation but also in politics in his Elegies (as cited in Mousely, 1999, p. 33).

Although Donne wrote "A Valediction: Forbidding Mourning" in 1611, after Elizabeth's death, and even though this poem is from his Song and Sonnets collection, not his Elegies, still one can follow the traces of his obsession with the female rule in his poem. Donne reveals his rejection of Petrarchan love sonnets which were prevalent in the Elizabethan age by composing this poem as an expression of his love for his wife, who is not an unattainable woman; however, still, he considers a woman as a center of power "And though in the center sit"(I. 29). To achieve the balance between his love and his desire for mastery, Donne expresses his admiration of the fixed foot of the compass on the one side, while, on the other side, he alludes to his desire for mastery in this relationship. Donne just uses a personal and romantic style to appreciate his love of life, the one who is the sovereign fixed foot, the ruler of their love relation; he considers himself to be only the roaming foot of the compass, hence her inferiority, her subservience, and dependence. He glorifies her consistency in love. However, obliquely and with social and political undertones, he alludes to the female monarch, Elizabeth I, as the fixed foot of the compass, himself and her subjects being its roaming foot. Thus, he extends the metaphor from the personal to the public level. The consistency in love also entails men's lack of original liberty that made them subservient to the authority of the queen. By referring to a woman as a center of power or the fixed foot of the compass, a sense of superiority is established. As soon as this sense of superiority is established, Donne announces a final twist by using the word lean. "Yet, when the other far doth roam, / It leans and hearkens after it"(II. 30-31). The rooted foot of the compass is tending to lean toward the other foot and then it grows erect by the assistance of the roaming foot of the compass." And grows erect, as that comes home" (I. 32). Now his tension over the submission to the female rule demonstrates itself by indicating the dependency of the fixed foot of the compass which is assigned to a self-centered female monarch to the other foot of the compass which is assigned to men as well as other members of society. Therefore, the structure of the sovereignty of the self-centered female monarch is deconstructed by the poetic persona's uncovering her dependence on all her subjects. This is reminiscent of the speech made by Laertes in Shakespeare's Hamlet (1599-1602) that best testifies to the heritage that forms Donne's point of view regarding a monarch's position in society,

His greatness weighed, his will is not his own, 
For he himself is subject to his birth.

He may not, as unvalued persons do,

Carve for himself, for on his choice depends

The sanctity and health of this whole state,

And therefore must his choice be circumscribed

Unto the voice and yielding of that body

Whereof he is the head. (I. iii. 17-25)

The quote reveals that the monarchs are not independent beings coming from another planet. They are as much human as other people are, and eventually, they have their types of limitations and dependence.

The historical backgrounds of Hāfez and Donne have, as shown above, been the impetus behind this study to examine the function of the compass in the political context, too. Both Hāfez and Donne utilize the compass metaphor to indicate their dissatisfaction with the rulers of their own time. This dissatisfaction can only be in the form of the internal conflict as evident in Donne's poetry which has a less social manifestation. Despite Donne's resentment, one cannot ignore the significant role of Elizabeth I in the improvement of England in political, social, literary and various other aspects whereas Hāfez's dissatisfaction has more intense social illustration since he criticizes the reign of a dictator, Mobarez-al-Din, and, by referring to the word, Äghelan, he extends his criticism to prove the deficiencies of those pretentious rationalists who are in charge of power and behave in the same manner as Mobarez-al-Din does.

\section{Conclusion}

The multilayered implications of the universal theme of love have informed the present study as a comparative analysis of Donne's "A Valediction: Forbidding Mourning" and Häfez's Sonnet193. The point of this comparison is the common utilization of the compass as a conceit by both Hāfez and Donne in the above-mentioned poems. Based on the Comparative Literature principles, the study aims to make a connection between two tempro-spatially aloof poets, one from $14^{\text {th }}$-century Iran and one from $16^{\text {th }}$ century England, to create a familiarity for the readers who come from two distinctly different languages and cultures. That is to say, the existence of analogous terminologies such as love, circle, and compass in these poems enabled the researchers of this study to compare the function of these terminologies in the poems of the two poets who came from separate social, political, and literary backgrounds. The results of comparing Häfez's utilization of the conceit in the sonnet 193 with that of Donne's in "A Valediction: Forbidding Mourning," show that both Donne and Hāfez have used the same mathematical tool, the compass, not only to comment on the meaning of love but also to criticize the political atmosphere of their time. In other words, love for both poets is just a disguise and the main premise and design of the two poems is the political censure. Love is a foil to politics, a contrast that is made by the two poets to show how the world has fallen apart because of a big displacement or a huge faulty replacement of love by politics. Because no previous research had concentrated on the comparative study of the two poets, we hope that this study will pave the way for further study of their poetic achievements.

\section{References}

[1] Anushiravani, Alireza (2010). Asibshenasi Adabiate Tatbighi dar Iran. Vizhenameh Adabiat Tatbighi Farhangestan 1(2), 32-55.

[2] Ashoori, Dariyoush (2016). Erfano Rendi dar Sheere Hāfez. $13^{\text {th }}$ ed. Tehran: Tajik.

[3] Bagheri Khalili, Aliakbar, \& Mehrabi Kali, M. (2014). Tarhvare charkheshi dar she're Hāfez va Saadi. Naghde Adabi 6(23), 125-148.

[4] Baha-ud-Din Khoramshahi (2013). Different Types of Love in the Poetry of Lesaan al-Gheib [Anvae Eshgh dar Ashaare Lesaan al-Gheib]. http://www.dana.ir/news/16929.html

[5] Cirillo A. R. (2016). The Fair Hermaphrodite: Love-Union in the Poetry of Donne and Spenser. SEL: Studies in English Literature1500-1900 9(1), 81-95.

[6] Clarke, Henry Wiberforce, trans. (2001). Ghazal of Häfez Shirazi: In Persian with English translation. Comp. Homayoun Far, Behrouz.

[7] Dezh Abad, Vali (2013). Anvae maashough dar sheere Hāfez. http://guilan-e-ma.ir

[8] Ebrahimi Dinaie, \& Hossein, G. (2012). Aghelan noghte pargare vojoudand. https://www.philosophyar.net

[9] Estelami, M. (2014). Darse Hāfez: Naghdo sharhe Ghazalhaye Hāfez. Tehran: Sokhan.

[10] Fathollahi, Mohammad Ali, \& Hosseini, Masoome (2014). The Political Philosophy of Khawaja Shams al-Din Mohammad Hāfez Shirazi.

Pazhouheshhaye Siasate Eslami 1(3),113-142.

[11] Freccero, John (2015). Donne's Valediction: Forbidding Mourning. ELH, 30(4), 335-376. 
[12] Greteman, Blaine (2010). All this seed pearl: John Donne and Bodily Presence. College Literature, 37(3), $26-42$.

[13] Guibbory, Achsah (2015). Oh, Let Mee Not Serve So: The Politics of Love in Donne's Elegies. ELH, 57(4), 811-833.

[14] Hadidi, Khalil, \& Mousazade, M. A. (2011). Jelvehaye kheradsetizi dar sheere Hāfez. Noormagz 36(223), 53-88.

[15] Hafez. Wikipedia, The Free Encyclopedia. Retrieved 21:17, June 24, 2021, from

https://en.wikipedia.org/w/index.php?title=Hafez\&oldid=1027469833

[16] Iranfar, Mohammad (2007). Pargar, Noghte, Dayere dar sheere Hafez. Noormagz 11(35), 63-65.

[17] Izadyar, Mohsen (2015). Barresi azad andishi dar sheere Hāfez. Faslname Elmi Tarviji Zaban Farsi 4(15),16-36.

[18]John Donne. Wikipedia, The Free Encyclopedia. Retrieved 21:41, June 21, 2021, from

https://en.wikipedia.org/w/index.php?title=John Donne\&oldid=1029039991

[19] Karimi, Najmeh (2015). Tabalvore Jameiyate Farhangi va Andishehaaye Hāfez dar sheere ou. Erfaniyat dar Adab Farsi 1(27),132-152.

[20] Khan, Gulfishan. 2009. Muslim-Western Cultural Encounter in the Eighteenth Century: The Impact of Hāfiz Shīrāzī'sPoetry on Europe. Islamic Studies, 48(1), 35-87. http://www.jstor.org/stable/20839153

[21] Lewishan, L (2010). Hāfez and tradition of love in classical Persian poetry. New York.

[22] Mansournejad, M. (2014). Mahiyate andishe siasi rende Shiraz, Hāfez. Oloum Siasi 16(61), 69-90.

[23] Modarres Zadeh, \& Reza, M. \& Anushirvani, A. (2016). Parallels of love in Rumi and Donne. International Journal of Comparative Literature and Translation Studies 4(4), 24-31.

[24] Mousely, A (1999). John Donne: Contemporary Critical Essays. London: MACMILLAN PRESS LTD.

[25] Naugle, David (2018). John Donne's poetic philosophy of love. http://fliphtml5.com/qjfd/ufyx

Oxford English Dictionary Online. http://en.oxforddictionaries.com

[26] Rivers, Isabel (1994). Classical and Christian Ideas in English Renaissance Poetry. Routledge.

[27] Sajjadi, Seyyed Mahdi, \& Mahdavi, Zeinab (2013). The Comparative Study: Aesthetic and Love in Hāfez and Goethe's poetry in order to awaken and bring perfection in Global Education. ERIC 8(23), 2233-2240.

28] Siegel, Paul N. (2015). The Petrarchan Sonneteers and Neo-Platonic Love. Studies in Philology 42(2), 164-182.

[29] Shakespeare, William (n. d.). The Tragedy of Hamlet Prince of Denmark. Folger Shakespeare Library. http:// www.folgerdigitaltexts.org

[30] Targoff, Ramie (2008). John Donne, Body and Soul. The University of Chicago Press. Chicago and London. 